\title{
Determination of Serum Albumin by its quenching effect on the fluorescence of $\mathrm{Zn}^{2+}$-Morin complex
}

\author{
Wei Huang a, Nan Caob and Feng Wang ${ }^{\mathrm{c}}$ \\ College of Chemistry, Chemical Engineering and Materials Science, Zaozhuang University, \\ Zaozhuang, 277160, P.R. China \\ ahw8586@163.com, ${ }^{\mathrm{b}}$ caonan6746@163.com, ${ }^{\mathrm{C}}$ wf3786621@163.com
}

Keywords: Morin, $\mathrm{BSA}, \mathrm{Zn}^{2+}$,fluorescence spectrum,UV absorption spectra.

Abstract. In this paper, the mode of action of Morin and protein has been studied through UV and fluorescence spectrum. This paper found that in the $\mathrm{pH}=8.50 \mathrm{Tris}-\mathrm{HCl}$ buffer solution, at the presence of $\mathrm{Zn}^{2+}$, the protein can cause Morin fluorescence quenching and the quenching degree of fluorescence is in proportional to the amount of protein to a certain extent. At the best condition, the detection limit of BSA and HSA is $0.22 \mu \mathrm{g} \cdot \mathrm{mL}^{-1} 、 0.18 \mu \mathrm{g} \cdot \mathrm{mL}^{-1}$ respectively. Compared with other analysis methods for proteins that have been reported,this method has a relatively wide linear range and high sensitivity.

\section{Introduction}

Morin (3, 5, 7, 2', 4'-pentahydroxyflavone) is the effective component of a common Chinese medicinal herb. Morin belongs to a kind of hydroxyl flavonoids and its structure as shown in Fig.1. Morin consists of two aromatic rings (A and B) linked by an oxygen-containing heterocycle (ring $\mathrm{C}$ ).

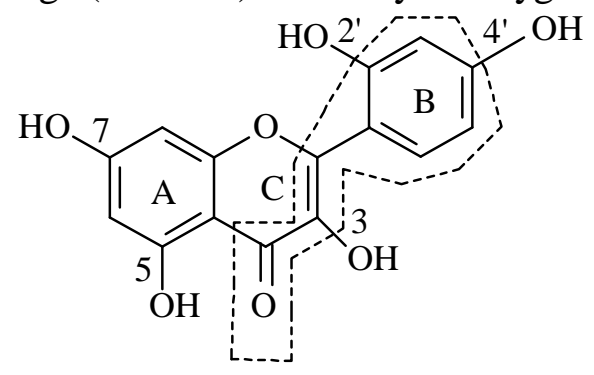

Fig.1. The structure of Morin

Recently, Morin has attracted more and more interest because it exhibits a broad spectrum of biological and important therapeutic applications (eg. antibiosis, antiphlogosis, antioxidation, antiviral, antitumor activities [1-3]). Morin exerts its functions on various proteins [4-8], so it is necessary to study the interaction between Morin and protein. Bovine serum albumin (BSA), a model protein that is frequently used as a testing ground for initial characterization of novel optical probes for proteins was chosen for the present investigation.

Previous work has primarily been about the usage of the intrinsic fluorescence emission properties of proteins [9-10]. In this paper, the intrinsic fluorescence of Morin is employed as a probe for understanding protein-natural flavonoid interaction from both qualitative as well as quantitative perspectives.

\section{Experimental}

Apparatus. Fluorescence spectra were recorded with an F-2500 spectrofluorometer (Hitachi, Japan). Absorption spectra were taken with an UV-2401PC spectrophotometer (Shimadzu, Japan). All pH measurements were made with a pHS-2F digital acidity meter (Leici, Shanghai, China). Three times distilled water was made by SZ-93A automatic dual water distiller (Yarong biochemical instrument factory, Shanghai ). Analytical balance is CP225D electronic balance (sartorius AG).

Reagents. Protein bovine serum albumin (BSA) and human serum albumin (HSA) were purchased from Shanghai Boao Biochemical Technology Co. and Sigma, respectively. Morin was purchased from 
Sigma-Aldrich. All the chemicals used were of analytical reagents grade, and deionized water was used for all experiments.

Stock solutions of BSA and HSA at $1.00 \mathrm{~g} \cdot \mathrm{L}^{-1}$ were prepared by dissolving them in water. The Morin solution at $4.00 \times 10^{-3} \mathrm{~mol} \cdot \mathrm{L}^{-1}$ was prepared by dissolving Morin in ethanol. The $\mathrm{Zn}^{2+}$ solution at $1.00 \times 10^{-3} \mathrm{~mol} \cdot \mathrm{L}^{-1}$ was prepared by dissolving $\mathrm{ZnCl}_{2}$ in water. A series of Tris $-\mathrm{HCl}$ buffer solutions $\left(0.2 \mathrm{~mol} \cdot \mathrm{L}^{-1}\right)$ were used for the $\mathrm{pH}$ adjustment. The above solutions were stored at $0-4^{\circ} \mathrm{C}$.

Procedures. For spectral measurement, all samples were prepared according to the following procedure: $1.00 \mathrm{~mL}$ Tris $-\mathrm{HCl}(\mathrm{pH} 8.50), 0.80 \mathrm{~mL}$ of Morin $\left(4.00 \times 10^{-4} \mathrm{~mol} \cdot \mathrm{L}^{-1}\right), 1.00 \mathrm{~mL}$ of $\mathrm{Zn}^{2+}$ $\left(1.00 \times 10^{-3} \mathrm{~mol} \cdot \mathrm{L}^{-1}\right)$ and certain standard BSA (or sample solution) in turn, and then the mixture was diluted to $10 \mathrm{~mL}$ with water and allowed to stand for 20 minutes. The fluorescence intensity was measured in a $1 \mathrm{~cm}$ quartz cell at $\lambda \mathrm{ex} / \lambda \mathrm{em}=320 \mathrm{~nm} / 520 \mathrm{~nm}$ with a slit of $10.0 \mathrm{~nm}$ for the excitation and emission. The quenched fluorescence intensity of Morin by BSA was represented as $\Delta \mathrm{I}_{\mathrm{f}}(\%)=\left(\mathrm{I}_{0}-\mathrm{I}_{\mathrm{f}}\right) /$ $\mathrm{I}_{0} \times 100 \%$. Here, $\mathrm{I}_{\mathrm{f}}$ and $\mathrm{I}_{0}$ were the intensities of the systems with and without BSA, respectively.

\section{Results and discussion.}

Fluorescence Spectra. The fluorescence spectra of the (1) Morin $+\mathrm{Zn}^{2+}$; (2) Morin $+\mathrm{Zn}{ }^{2+}+\mathrm{BSA}$; (3) Morin; (4) Morin+BSA ; (5) $\mathrm{Zn}^{2+}+\mathrm{BSA}$;(6) $\mathrm{Zn}^{2+}$;(7) BSA systems are shown in Fig.2. From this figure, It can be seen that in a Tris $-\mathrm{HCl}$ buffer at $\mathrm{pH}=8.50$, after the excitation of $320 \mathrm{~nm}$, the intensity of characteristic fluorescence of BSA at the emission peak of $520 \mathrm{~nm}$ can be quenched by the addition of Morin $+\mathrm{Zn}^{2+}$. This indicates that there is interaction among Morin $+\mathrm{Zn}^{2+}$ and BSA.
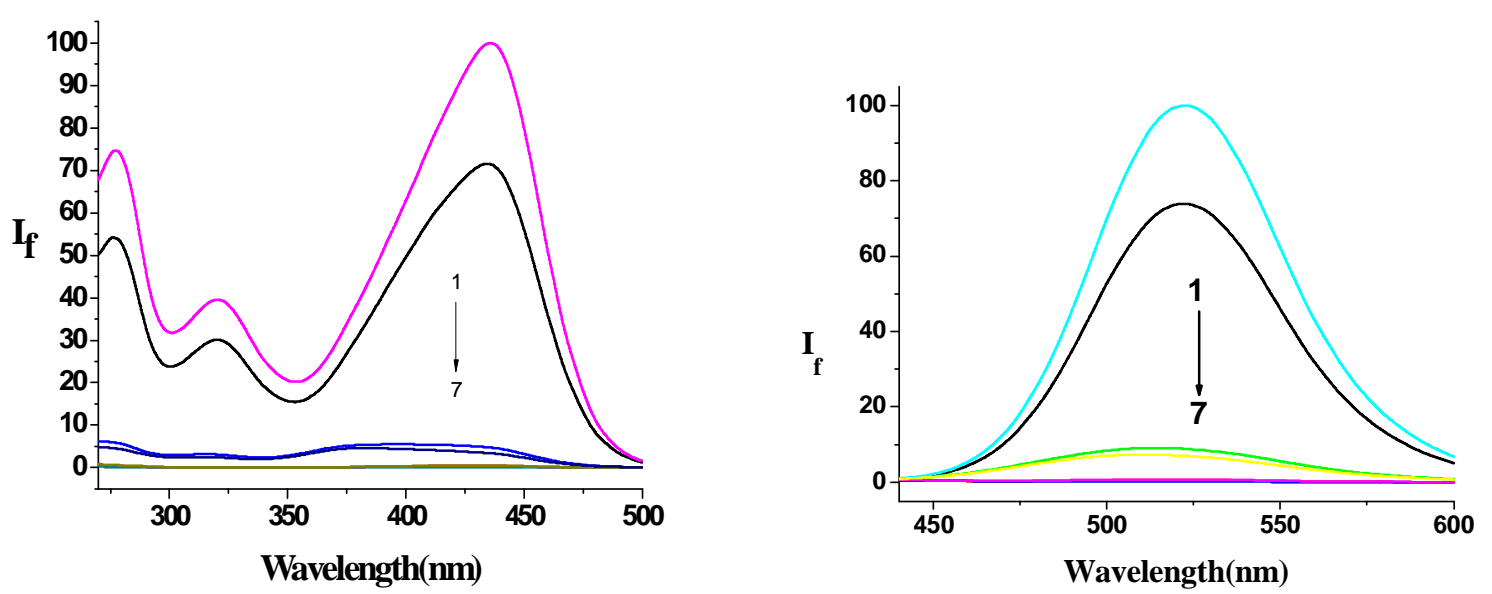

Fig. 2 Excitation spectra (a) $(\lambda e m=520 \mathrm{~nm})$ and emissionspectra (b) $(\lambda e x=320 \mathrm{~nm})$ 1.buffer+Morin $+\mathrm{Zn}^{2+} ;$ 2.buffer+Morin $+\mathrm{Zn}^{2+}+\mathrm{BSA} ; 3$.buffer+Morin ; 4.buffer+Morin+BSA ;

$$
\text { 5.buffer }+\mathrm{Zn}^{2+}+\mathrm{BSA} ; 6 \text {.buffer }+\mathrm{Zn}^{2+} ; \text { 7.buffer+BSA }
$$

Conditions: $\mathrm{pH}=8.50$; Morin: $3.20 \times 10^{-5} \mathrm{~mol} \cdot \mathrm{L}^{-1} ; \mathrm{Zn}^{2+}: 1.00 \times 10^{-4} \mathrm{~mol} \cdot \mathrm{L}^{-1} ; \mathrm{BSA}: 0.050 \mathrm{~g} \cdot \mathrm{L}^{-1}$;

Effects of $\mathbf{p H}$ and Buffers. The effect of $\mathrm{pH}$ on the quenched fluorescence intensity $\Delta \mathrm{I}_{\mathrm{f}}(\%)$ of the system is shown in Fig. 3. The experimental results indicate that the $\Delta \mathrm{I}_{\mathrm{f}}(\%)$ reaches a maximum around $\mathrm{pH}=8.50$. The effects of different buffers on the $\Delta \mathrm{I}_{\mathrm{f}}(\%)$ of this system are also tested at the same $\mathrm{pH}$ $(\mathrm{pH}=8.50)$. The $\Delta \mathrm{I}_{\mathrm{f}}(\%)$ for Tris-HC;Borax; $\mathrm{KH}_{2} \mathrm{PO}_{4}-\mathrm{NaOH}$; BR-; citric acid - $\mathrm{NaOH}$ are 100, 35.89; $-1.16 ;-1.62 ;-5.17$ respectively. So Tris-HC is the most suitable buffer. Tris-HC buffer solution 
$(\mathrm{pH}=8.50)$ was selected for the assay and the optimum volume is $1.00 \mathrm{~mL}$.

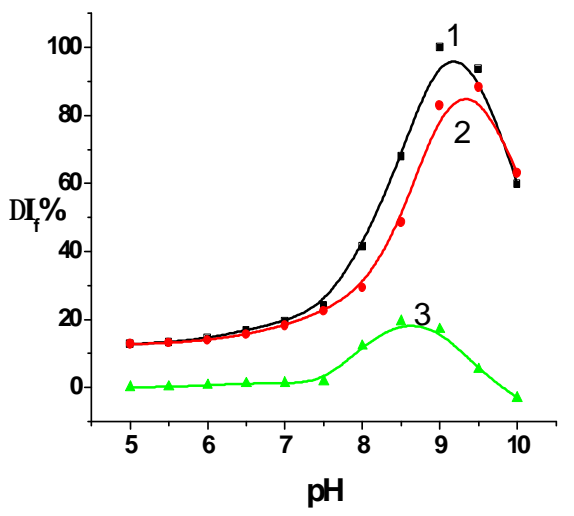

Fig. 3 The effect of $\mathrm{pH}$ on the fluorescence intensity $1: \mathrm{I}_{\mathrm{f}}^{0} ; 2: \mathrm{I}_{\mathrm{f}} ; 3 \mathrm{I}_{\mathrm{f}}^{0}-\mathrm{I}_{\mathrm{f}}$

Conditions: $\mathrm{pH}=8.50$; Morin: $3.20 \times 10^{-5} \mathrm{~mol} \cdot \mathrm{L}^{-1}$;

$\mathrm{Zn}^{2+}: 1.00 \times 10^{-4} \mathrm{~mol} \cdot \mathrm{L}^{-1}$; BSA:0.050g. $\mathrm{L}^{-1}$;

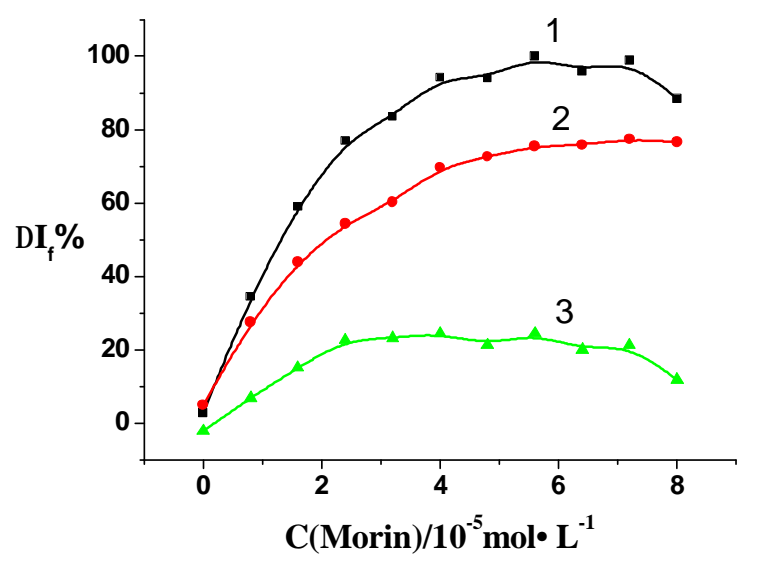

Fig. 4The effect of the concentration of Morin $1: \mathrm{I}_{\mathrm{f}}^{0} ; 2: \mathrm{I}_{\mathrm{f}} ; 3 \mathrm{I}_{\mathrm{f}}^{0}-\mathrm{I}_{\mathrm{f}}$

Conditions: $\mathrm{pH}=8.50 ; \mathrm{Zn}^{2+}: 1.00 \times 10^{-4} \mathrm{~mol} \cdot \mathrm{L}^{-1}$; BSA:0.050g. $\mathrm{L}^{-1}$;

Effect of Morin Concentration. The effect of Morin concentration on the fluorescence intensity of Morin-BSA- $\mathrm{Zn}^{2+}$ system is studied. From Fig. 4, it is found that the quenched fluorescence intensity of Morin system reaches a maximum when the concentration of Morin is $3.20 \times 10^{-5} \mathrm{~mol} \cdot \mathrm{L}^{-1}$. So $3.20 \times 10^{-5} \mathrm{~mol} \cdot \mathrm{L}^{-1}$ of Morin is chosen in the research.

Effect of $\mathbf{Z n}^{2+}$ concentration. The effect of $\mathrm{Zn}^{2+}$ concentration on the fluorescence intensity of Morin-BSA- $\mathrm{Zn}^{2+}$ system is studied.It is found that the quenched fluorescence intensity of $\mathrm{Zn}^{2+}$ system reaches a maximum when the concentration of $\mathrm{Zn}^{2+}$ is $1.00 \times 10^{-4} \mathrm{~mol} \cdot \mathrm{L}^{-1}$. So $1.00 \times 10^{-4} \mathrm{~mol} \cdot \mathrm{L}^{-1}$ of $\mathrm{Zn}^{2+}$ is chosen in the research.

Effect of reaction time Tests show that the $\Delta \mathrm{I}_{\mathrm{f}}$ reached a maximum within 20 minutes after reagents had been added, and the $\Delta \mathrm{I}_{\mathrm{f}}$ remained stable for at least 2 hours. Therefore the system exhibited good stability. In this research, 20 minutes of sample incubation time was set for all the fluorescence measurements.

Interfering substances. With the standard analytical procedure established at the above optimized condition, interferences of foreign substances including various ions and biomolecules on fluorescence of the Morin-BSA- $\mathrm{Zn}^{2+}$ system were evaluated. The results in Table 1 indicate that these foreign substances had little or no effect on the determination of proteins under the permission of $\pm 5 \%$ relative errors, and thus the proposed method exhibits good selectivity in protein measurement.

Table1 Interference from foreign substances

\begin{tabular}{|c|c|c|c|c|c|}
\hline $\begin{array}{c}\text { Foreign } \\
\text { substances }\end{array}$ & $\begin{array}{c}\text { Concentration } \\
\left(10^{-6} \mathrm{~mol} \cdot \mathrm{L}^{-1}\right)\end{array}$ & $\begin{array}{l}\Delta \mathrm{I}_{\mathrm{f}} \\
(\%) \\
\end{array}$ & $\begin{array}{c}\text { Foreign } \\
\text { substances }\end{array}$ & $\begin{array}{c}\text { Concentration } \\
\left(10^{-6} \mathrm{~mol} \cdot \mathrm{L}^{-1}\right)\end{array}$ & $\begin{array}{r}\Delta \mathrm{I}_{\mathrm{f}} \\
(\%) \\
\end{array}$ \\
\hline $\mathrm{Na}^{+}, \mathrm{Cl}^{-\mathrm{f}}$ & 2 & -3.98 & $\mathrm{Mg}^{2+}, \mathrm{SO}_{4}{ }^{2-}$ & 2 & -2.85 \\
\hline $\mathrm{Ca}^{2+}, \mathrm{Cl}^{-}$ & 2 & -3.18 & $\mathrm{Cu}^{2+}, \mathrm{Cl}^{-}$ & 2 & -5.95 \\
\hline $\mathrm{NH}_{4}^{+}, \mathrm{Cl}^{-}$ & 2 & -2.71 & $\mathrm{Zn}^{2+}, \mathrm{SO}_{4}{ }^{2-}$ & 2 & -2.92 \\
\hline $\mathrm{Zn}^{2+}, \mathrm{Cl}^{-}$ & 2 & -3.84 & L-Glu & 2 & -3.69 \\
\hline $\mathrm{Mn}^{2+}, \mathrm{Cl}^{--}$ & 2 & -4.67 & sucrose & 2 & -4.50 \\
\hline $\mathrm{Na}^{+}, \mathrm{SO}_{4}^{2-}$ & 2 & 4.55 & L-Leu & 2 & -5.75 \\
\hline $\mathrm{K}^{+}, \mathrm{Cl}^{-}$ & 4 & -3.76 & Glucose & 2 & -5.94 \\
\hline
\end{tabular}

$\mathrm{pH}=8.50 ;$ Morin: $3.20 \times 10^{-5} \mathrm{~mol} \cdot \mathrm{L}^{-1} ; \mathrm{BSA}: 5.0 \times 10^{-4} \mathrm{~g} \cdot \mathrm{L}^{-1} ; \mathrm{Zn}^{2+}: 0.80 \times 10^{-4} \mathrm{~mol} \cdot \mathrm{L}^{-1}$ 


\section{Analytical parameters}

Under the optimum conditions defined, the calibration graphs for BSA and HSA were obtained. They showed that there was a linear relationship between the $\Delta \mathrm{I}_{\mathrm{f}}$ and the concentration of proteins listed in Table 2. It shows that this method has high sensitivity and a wide linear range. It can be seen that this method has a higher sensitivity and a wider linear range for protein measurement.

Table2 Analytical parameters of this method

\begin{tabular}{ccccc}
\hline & $\begin{array}{c}\text { Linear range } \\
\left(\mathrm{g} \cdot \mathrm{mL}^{-1}\right)\end{array}$ & $\begin{array}{c}\text { Linear regression } \\
\text { equation }\end{array}$ & $\begin{array}{c}\text { Correlation } \\
\text { coefficient } \mathrm{r}\end{array}$ & $\begin{array}{c}\text { Limit of } \\
\text { detection }\left(\mu \mathrm{g} \cdot \mathrm{mL}^{-1}\right)\end{array}$ \\
BSA & $4.00 \times 10^{-7}-1.00 \times 10^{-4}$ & $\Delta \mathrm{I}_{\mathrm{f}}=14.57+43.14 \mathrm{C}$ & 0.9910 & 0.22 \\
$\mathrm{HSA}$ & $4.00 \times 10^{-7}-1.00 \times 10^{-4}$ & $\Delta \mathrm{I}_{\mathrm{f}}=14.65+52.21 \mathrm{C}$ & 0.9922 & 0.18 \\
\hline
\end{tabular}

\section{Conclusion}

In this work, the fluorescence property of the Morin-BSA-- $\mathrm{Zn}^{2+}$ system has been systematically investigated by using UV absorbance spectroscopy and fluorescence spectroscopy techniques. Results show that the fluorescence of Morin or BSA can all be intensely quenched by the other. The quenching in Morin fluorescence intensity is quantitatively proportional to the concentration of proteins in a wide range.

\section{Acknowledgements}

The project of this paper are supported by Shandong Provincial Natural Science Foundation(ZR2012BL06) and Higher school teaching reform project in shandong province (2012496).

\section{References}

[1] T. W. Wu, K. P. Fung, J. Wu, et al. Morin hydrate inhibits azo-initiator- induced oxidation of human low-density lipoprotein, Life Sci., 58(1996): 17-22

[2] L. D. S. Kok, Y. P. Wong, T. W. Wu, et al. Morin hydrate A potential antioxidant in minimizing the free-radicals-mediated damage to cardiovascular cells by anti-tumor drugs, Life Sci., 67(2000): 91-99

[3] V. Sivaramakrishnan, P. Shilpa, V. Kumar, et al. Attenuation of N-nitrosodiethylamine-induced hepatocellular carcinogenesis by a novel flavonol-Morin, Chem. Biol. Interact., 171(2008): 79-88

[4] Z.F. Yu, W.P. Fong, CH. K. Cheng, The dual actions of Morin (3, 5, 7, 2', 4'-penta-hydroxyl flavone) as a hypouricemic agent: uricosuric effect and xanthine oxidase inhibitory activity, J. Pharmacol. Exp. Ther. 316 (2006) 169-175.

[5] J. Brown, J. O'Prey, P. R. Harrison, Enhanced sensitivity of human oral tumours to the flavonol, Morin, during cancer progression: involvement of the Akt and stress kinase pathways, Carcinogenesis 24 (2003) : $171-177$.

[6] D.G. Kang, M.K. Moon, E.J. Sohn, et al. Effects of Morin on blood pressure and metabolic changes in fructose-induced hypertensive rats, Biol. Pharm. Bull. 27 (2004): 1779-1783.

[7] C.V. Iglesias, R. Aparicio, L. Rodrigues-Simioni, et al. Effects of Morin on snake venom phospholipase A2 (PLA 2), Toxicon 46 (2005): 751-758.

[8] C.Y. Hsiang, S.L.Wu, T.Y. Ho, Morin inhibits 12-O-tetradecanoylphorbol- 13- acetate-induced hepatocellular transformation via activator protein 1 signaling pathway and cell cycle progression, Biochem. Pharmacol. 69 (2005): 1603-1611.

[9] M. X. Xie, M. Long, Y. Liu, et al. Characterization of the interaction between human serum albumin and Morin. Biochimica et Biophysica Acta 1760 (2006): 1184-1191

[10]Z. D. Qi, Y. Zhang, F. L. Liao, et al. Probing the binding of Morin to human serum albumin by optical spectroscopy. J. Pharm. Biomed. Anal. 46 (2008): 699-706 